\title{
EXPRESSION OF NARROW FOCUS IN SPONTANEOUS ESTONIAN DIALOGUES
}

\author{
Heete Sahkai \\ Institute of the Estonian Language
}

\begin{abstract}
Estonian offers several means for expressing narrow focus, including a choice between a syntactic strategy resulting in marked constituent order, and a prosodic strategy resulting in marked nuclear accent placement. The present study examines the usage of the different focus-marking strategies in spontaneous dialogues, with the primary aim of verifying the hypothesis that when either the syntactic or the prosodic strategy must be used, the prosodic strategy is preferred. The results show an overwhelming preference for keeping both the constituent order and the accent placement unmarked. In the relatively small number of cases where either the syntactic or the prosodic strategy must be chosen, a slight preference for the prosodic strategy can be observed. There also exists a minor strategy of focus fronting, whereby both the constituent order and the nuclear accent placement are marked; the role of this strategy requires further study.
\end{abstract}

Keywords: Estonian, focus, constituent order, sentence accent

DOI: https://doi.org/10.12697/jeful.2017.8.2.12

\section{Introduction}

This paper examines the expression of narrow focus in spontaneous Estonian dialogues. Focus can be defined pragmatically as " $[t]$ he semantic component of a pragmatically structured proposition whereby the assertion differs from the presupposition" (Lambrecht 1994: 213). For instance, sentence (1), when uttered in response to the question "Who will pay the bill?", evokes the presupposition that someone will pay the bill, and asserts that the person in question is me, which is consequently the focus of the proposition conveyed by the sentence.

(1) I will pay the bill.

The size of the focus can vary from the entire sentence to a single constituent. In the above example, "I" is an instance of narrow focus 
(argument focus in terms of Lambrecht 1994), whereby a single constituent of a clause is in focus. If sentence (1) had been uttered in response to the question "What will you do?", the focus would include the VP "will pay the bill" and would be an instance of predicate focus, the subject of the sentence being the topic, i.e. the constituent about whose referent the proposition is construed to be (Lambrecht 1994: 131). And if the same sentence had been uttered in response to a question such as "What next?", the entire sentence would be in focus as it evokes no presupposition and is not pragmatically structured into topic and focus.

While sentence focus is conveyed by the unmarked form of utterances in a language, the expression of topics and narrow foci may involve marked structures. Cross-linguistically, narrow focus can be expressed by various means, which are primarily syntactic and prosodic in nature. In head-prominence languages like Estonian, i.e. languages where phrasal prominence is expressed with phrasal pitch accents aligned with the primary-stressed syllables of words (Jun 2005), the prosodic expression of narrow focus consists in the placement of the nuclear accent (i.e. the last accent in a sentence, cf. Ladd 2008: 257-259) on the focused constituent. The syntactic expression of narrow focus consists in the placement of the focal constituent in a dedicated syntactic position, which may coincide with the unmarked position of the nuclear accent. Vallduví (1991) considers these two strategies complementary: either the position of the nuclear accent follows the position of the focal constituent, which remains in its neutral syntactic position, or the placement of the focal constituent follows the unmarked position of the nuclear accent, which remains in its unmarked position. This gives rise to a typological categorisation of languages into languages with plastic and non-plastic intonation (exemplified for instance by English and Catalan, respectively). Van Valin (1999) proposes a broader typology, adding to these two categories languages with both flexible (plastic) constituent order and flexible prosody (e.g. Russian), and languages where both syntax and prosody are fixed (e.g. French).

Estonian can be considered to be a language with both plastic syntax and plastic intonation. Tael (1988) identifies information structure as the determining factor of the Estonian word order (together with the verb-second principle), which implies that Estonian is a discourseconfigurational language like Finnish (Vilkuna 1989) and Hungarian (É. Kiss 1987). In written data, there is a general tendency for topics to be sentence-initial and foci to be sentence-final; contrastive foci can 
also be sentence-initial (Tael 1988: 40). Similarly, Lindström (2005) finds that in spoken data, new information (which tends to coincide with focus, cf. Lambrecht 1994: 257-264) tends to come later in the sentence. A sentence-final focus coincides with the unmarked placement of the nuclear accent, which, in line with a universal cross-linguistic tendency (Ladd 2008: 252), can be considered to be on the last content word of the sentence.

At the same time, there is clear evidence that Estonian also has plastic nuclear accent placement, one of the factors that cause the nuclear accent to appear earlier in the sentence being non-final narrow focus. Erelt et al. (1993: 195) list four means by which narrow focus can be expressed: (i) emphatic stress (esiletõsterõhk), which can be interpreted as an emphatic nuclear accent accompanied by the deaccentuation of the post-focal sequence, cf. (2); (ii) emphatic stress together with a focus particle, (3); (iii) emphatic stress together with the placement of the focal constituent in the sentence-final position, (4); and (iv) emphatic stress together with focus fronting, i.e. the placement of the focal constituent in the sentence-initial position, which means that this strategy involves both marked syntax and marked prosody, (5).

(2) MINA opetasin sind.

1SG.NOM teach.PAST.1SG 2SG.PART

'I (was the one who) taught you.'

(3) MINA ju oppetasin sind.

1SG.NOM PRTCL teach.PAST.1SG 2SG.PART

'I (was the one who) taught you.'

(4) Sind öpetasin (ju) MINA.

2SG.PART teach.PAST.1SG PRTCL 1sG.NOM

'I (was the one who) taught you.'

(5) IGAV on ootaja aeg.

tedious.NOM be.3 someone.who.waits.GEN time.NOM

'Tedious is the time for someone who waits.'

Recent experimental studies have confirmed that marked nuclear accent placement is indeed used and interpreted to express narrow focus. Sahkai et al. (2013) found that when asked to describe a picture 
in response to a question eliciting narrow focus on the subject, the test subjects overwhelmingly used the prosodic focusing strategy by placing the nuclear accent on the subject and deaccenting the remaining part of the utterance, the word order remaining unchanged. Salveste (2013, 2015) in turn found that the word carrying the nuclear accent is interpreted as focal independent of its syntactic position.

The prosodic marking of narrow focus may also involve the realisation of the focused constituent in a separate prosodic phrase. Sahkai et al. (2013) found evidence of a tendency to phrase separately sentenceinitial, but not sentence-final narrow foci.

Consequently, Estonian can use both syntactic and prosodic marking to express narrow focus (including at the same time). This raises the question as to what is the division of labour between the two strategies. A possible hypothesis is that the prosodic marking is used in spoken language and the syntactic strategy in written language. This hypothesis is suggested by Lindström's (2005) finding that in spoken Estonian data, word order varies less than in written data. The hypothesis is also supported by Vilkuna's (1989) observation that in Finnish, the information structure-driven word order principles are operative in written language, whereas in spoken language the same categories are expressed prosodically. The aim of the present study is to examine the expression of narrow focus in spoken Estonian in order to verify whether it tends to be expressed by using the prosodic strategy, i.e. whether the prosodic strategy tends to be preferred where either the syntactic or the prosodic strategy must be chosen.

\section{Data and method}

The data come from the Corpus of Spoken Estonian assembled and transcribed at the Institute of Estonian and General Linguistics of the University of Tartu ${ }^{1}$. I analysed manually ten conversations between travel agents and customers: two face-to-face conversations and eight telephone conversations. I chose customer service dialogues because they consist in giving information and contain many questionanswer pairs, being thus easier to analyse for information structure than informal everyday conversations or monologues. From customer

\footnotetext{
1 Description of the corpus is available online at $<\mathrm{http}: / / \mathrm{www} . c l . u t . e e /$ suuline/Korpus $>$. Accessed on 21.04.2017.
} 
service dialogues, I chose travel agency dialogues because they were longer than the others. Travel agency conversations constitute a large subgroup in the corpus and the individual dialogues were chosen on the basis of the quality of the sound recording.

For the purposes of the analysis, I labelled all narrow foci found in non-elliptical affirmative declarative clauses ${ }^{2}$, taking into account both the transcriptions and the sound recordings of the dialogues. Narrow foci were identified on the basis of the context, e.g. the interlocutor's question $(6 a)^{3}$, or an earlier utterance of the speaker (6b) (narrow foci in bold).

a. Q: aga = kuskile 'mujale?
but to.anywhere else

'But to anywhere else?'

\section{A: $\ddot{A} \ddot{a}$ 'Austriasse on. \\ Uh Austria.ILl be. 3}

'There is to Austria.'

b. noh $m a=e i=$ tea mida te silmas peate.

well 1.SG NEG know REL.PART 2.PL mind.INESS have.2PL

$$
\begin{aligned}
& k u i=t e=\text { \{sellist }\} \text { 'rühmareisi silmas peate } \\
& \text { if } 2 \mathrm{PL} \text { such.PART group.tour.PART mind.INESS have.2PL }
\end{aligned}
$$

'I don't know what you have in mind. If you have in mind a group tour'

The focus constituents are either single arguments, adjuncts, or predicate complements that do not involve coordination, enumerations or clausal modifiers, which may independently influence the syntactic position of the constituent (Lindström 2005). Three instances of narrow foci were discarded from the data because they occurred in "syntactic blends" and consequently their position in the sentence could not be uniquely identified either as marked or unmarked, or as initial or final. One instance of narrow focus was omitted because the element in

2 Clauses were identified on the basis of syntactic structure and the punctuation marks used in the transcriptions.

3 Transcription conventions: (.) - micropause ( $0.2 \mathrm{sec}$ or less); (1.2) - length of the pause in seconds; ' - stress; $>$..<- accelerated speech; $<\ldots>-$ slow speech; : - lengthened syllable;@...@-marked intonation; (h) - laughter; si- - interrupted word; =-pronounced as one word; $[\ldots]$ - overlapping. 
focus was smaller than a constituent (an element of a complex numeral expression) and hence syntactically fixed.

The data were divided into four categories depending on the focusing strategy (the categories are illustrated with invented examples):

1. Phonetic strategy: sentences where the narrow focus is located in the sentence-final position, which is its unmarked position, e.g.:

$$
\begin{aligned}
& \text { Q: Mida naine sö̈b? } \\
& \text { Q.PART woman.NOM eat.3sG } \\
& \text { 'What is the woman eating?' }
\end{aligned}
$$
A: Naine sö̈b öuna. woman.NOM eat.3sG apple.PART
'The woman is eating an apple.'

I term this strategy "phonetic" because it has been found that although sentences with final narrow focus are syntactically and phonologically ${ }^{4}$ identical to broad-focus sentences, they are nevertheless distinguished from the latter by an emphatic phonetic realisation of the nuclear accent ${ }^{5}$ (and a reduced realisation of the preceding accents), as has been shown both by production and perception studies (Mihkla et al. 2015, Sahkai et al. 2014, 2015).

This category includes the cases where the focused constituent is in the sentence-final position because a constituent that normally follows it in the unmarked order is located in the sentence-initial topic position. It also includes the cases where a constituent that normally occurs earlier in the sentence has been right-dislocated to the post-focal position.

2. Syntactic strategy: sentences where the narrow focus is located in the sentence-final position as a result of a modification of the unmarked constituent order, e.g.:

$$
\begin{aligned}
& \text { Q: Kes sööb ouna? } \\
& \text { who eat.3SG apple.PART } \\
& \text { 'Who is eating an apple?' } \\
& \text { A: Õuna söo naine. } \\
& \text { apple.PART eat.3SG woman.NOM }
\end{aligned}
$$

'The woman is eating an apple.'

4 That is, in terms of prosodic phrasing, and the distribution and type of pitch accents.

5 Emphasis has been shown to be a gradual rather than a categorical phenomenon by Ladd and Morton (1997). 
This strategy is available in sentences where the unmarked position of the narrowly focused constituent is not sentence-final.

3. Phonological strategy: the focal constituent occurs in its unmarked position that is not sentence-final, focus being expressed by the marked location of the nuclear accent, e.g.:

$$
\begin{aligned}
& \text { Q: Kes sööb öuna? } \\
& \text { who eat.3sG apple.PART } \\
& \text { 'Who is eating an apple?' }
\end{aligned}
$$
A: Naine sööb õuna. woman.NOM eat.3sG apple.PART

'The woman is eating an apple.'

This strategy can occur under the same circumstances as the syntactic strategy.

4. Double phonological and syntactic strategy (focus fronting): the narrow focus occurs in the sentence-initial position that is not its neutral location, e.g.:

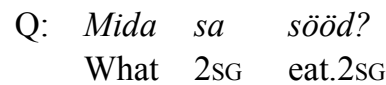

$$
\begin{aligned}
& \text { 'What are you eating?' }
\end{aligned}
$$

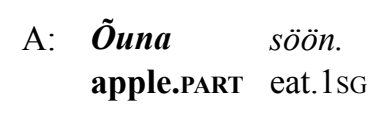

'I'm eating an apple.'

This strategy is in principle available whenever the focus is on a constituent whose neutral position is non-initial.

For the purposes of the analysis, I assumed the unmarked word order to be: subject - finite verb - dative-like argument corresponding to the indirect object (latiivne valdajamäärus) - adjunct - direct object / oblique argument / predicate complement - non-finite element of a phrasal verb - the main verb of a periphrastic verb form (Sahkai 1999: 29, Lindström 2017). In sentences with a marked topic, the unmarked position of the subject was assumed to be immediately post-verbal, e.g. Homme söön ma õuna 'tomorrow eat.1sG 1sG apple.PART" "Tomorrow I will eat an apple".

In existential sentences and sentences with an initial oblique experiencer or possessor argument, the unmarked order was assumed to be: 
setting adjunct / oblique argument - verb - subject (Erelt et al. 1993: 14-15). Accordingly, sentences of these types were considered to display (i) the phonetic strategy when the focus was on the sentencefinal subject (e.g. Metsas leidub [seeni]F 'forest.INEss be.found.3sG mushroom.PART.PL" "There are mushrooms in the forest"), (ii) the syntactic strategy when the focus followed the non-finite element of a complex predicate (Metsas pidavat leiduma [seeni]F 'forest.INESS must. QUOT be.found.INF mushroom.PART.PL' "I hear there are mushrooms in the forest") or occurred on the inverted setting adjunct/oblique argument (Seeni leidub [metsas]F), (iii) the phonological strategy when the focus was on the sentence-initial adjunct (e.g. [Metsas]F leidub seeni) or preceded the non-finite element of a complex predicate (Metsas pidavat [seeni] F leiduma), and (iv) the double-marking strategy when the focal subject occurred sentence-initially (e.g. [Seeni]F leidub metsas).

In impersonal and identificational sentences, the unmarked word order has been described as being governed by information structure. In an impersonal clause, the unmarked position of a verbal complement can be considered to be postverbal when it refers to new information, and preverbal when it refers to given information (Nurme 2012, Lindström 2017). In identificational sentences (e.g. Eesti pealinn on Tallinn "The Estonian capital is Tallinn"), the unmarked order is: topic copula - focus, depending on which of the two arguments is the topic and which is the focus (Erelt et al. 1993: 57). These types of sentences were considered to represent (i) the phonetic strategy when the focus-last order was respected, (ii) the syntactic strategy when the focus followed the non-finite element of a complex predicate (or a complement or adjunct that normally follows it), (iii) the phonological strategy when the focal constituent preceded the non-finite element of a complex predicate (or a complement or adjunct that normally follows it), and (iv) the double-marking strategy when the focal constituent was sentence-initial.

I also paid attention to whether the focus constituent constituted a separate prosodic phrase, as has been found to some extent to be the case with early focus (see above). To identify the prosodic phrase boundaries, I used the methodology developed for the purposes of labelling intonation phrases in the Phonetic Corpus of Estonian Spontaneous Speech ${ }^{6}$, described e.g. in Asu et al. (2016).

6 The corpus is available online at $<$ http://www.keel.ut.ee/en/languages-resourceslanguagesresources/phonetic-corpus-estonian-spontaneous-speech>. Accessed on 21.04.2017. 


\section{Results}

The data included in total 221 sentences. Four sentences were discarded in the course of the analysis because the focus constituent and the nuclear accent did not coincide, making it impossible to categorise these sentences in any of the four focus-marking categories. In all these cases the focal constituent was at the beginning of the sentence, as a result of syntactic focus fronting, but the nuclear accent was in its usual sentence-final position. For instance, in (11), the focus is the temporal adjunct at the beginning of the sentence, but the nuclear accent occurs on the sentence-final subject Finjet, which has been earlier mentioned by the speaker and about which new information is being given.

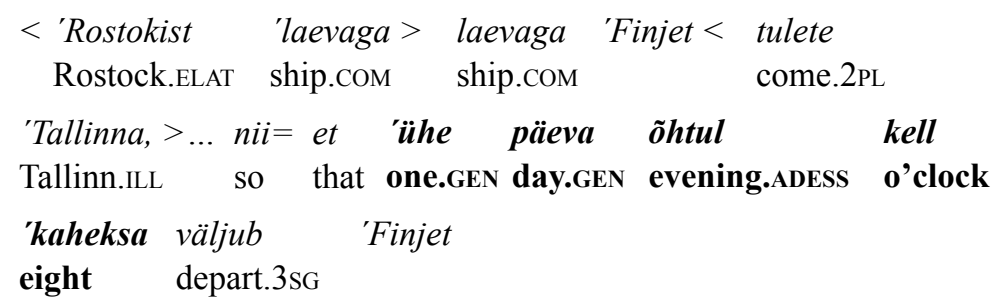

'You'll travel from Rostock to Tallinn with the ship Finjet ... so that Finjet departs at eight on one evening'

The distribution of the four focus-marking strategies in the remaining 217 sentences is presented in Table 1. The results are presented separately for the different sentence types found in the data, in order to reflect the fact that approximately three quarters of the sentences in the data involved the copula olema 'be' as the main verb. The first row shows the distribution of the focusing strategies in the 57 normal (i.e. neutrally subject-initial, cf. Erelt et al. 1993:14) sentences containing a full content verb (including 18 impersonal verbs). The second row shows the results for normal sentences containing a copula complemented either by an adjunct (usually a temporal or spatial adjunct, 37 instances) or by a predicate complement (67 instances, including 9 identificational sentences). The third row reports the results for the sentences with neutral subject-final order, i.e. existential sentences and sentences beginning with an oblique experiencer or possessor argument (56 instances); in these sentences as well the verb is usually olema 'be'?

7 Alternatively, the constituents complementing a copula could be interpreted as being part of the predicate and hence the corresponding sentences could be considered as predicate-focus sentences. In the present study, however, focus on the complement of a copula was analysed as narrow focus. 
Table 1. Distribution of the four focus-marking strategies in the different sentence types found in the data.

\begin{tabular}{l|c|c|c|c|c} 
& Phonetic & Syntactic & $\begin{array}{l}\text { Phono- } \\
\text { logical }\end{array}$ & Double & TOTAL \\
\hline $\begin{array}{l}\text { Normal sentences } \\
\text { with content verb }\end{array}$ & 27 & 9 & 10 & 11 & 57 \\
\hline $\begin{array}{l}\text { Normal sentences } \\
\text { with copula }\end{array}$ & 88 & 2 & 4 & 10 & 104 \\
\hline Subject-final sentences & 32 & 4 & 4 & 16 & 56 \\
\hline TOTAL & 147 & 15 & 18 & 37 & 217
\end{tabular}

As can be seen from the table, the majority of the sentences instantiate the phonetic strategy, whereby the focus constituent is located in its unmarked position at the end of the sentence. This tendency is weakest in the sentences containing a content verb (represented in $47 \%$ of all the sentences of this type) and strongest in normal copular sentences (in $85 \%$ of all the copular sentences), which in turn is by far the preferred sentence type in the data. The phonetic strategy is illustrated in examples (12-14):

(12) Normal sentence with content verb

('Lapimaa=reise me=teeme 'kaks korda nü̈̈d detsembri'kuus,)

üks $=a k k a b$ 'kolmteist detsember

one.NOM start.3SG thirteen.NOM december.NOM

'(We will organise two Lapland tours in December,) one starts on 13 December'

(13) Normal sentence with copula

('keldri korrusel 'tubades ei ole veetseed ja 'dušši ...)

$\begin{array}{lllll}\text { et need 'toad } & \text { on natukene 'odavamad. } \\ \text { that this.NOM.PL room.NOM.PL } & \text { be.3 } & \text { a.little.bit cheaper.NOM.PL }\end{array}$

'(On the basement floor the rooms don't have WC and shower...) These rooms are a little bit cheaper.'

(14) Subject-final sentence

(meie meil ei='ole praegu selliseid=ee Eu'roopa=reise)

meil $=$ on sellised 'väiksemad reisid.

1.PL.ADESS be.3 such.NOM.PL smaller.NOM.PL tour.NOM.PL

'(At present we don't have European tours,) we have smaller tours.' 
In the sentences where the unmarked position of the focus constituent is sentence-final, neither the syntactic nor the phonological strategy could have been used as an alternative focusing strategy. However, an alternative strategy was available in terms of the double-marking strategy, which is excluded only in cases where the neutral position of the focused constituent is sentence-initial. Despite the broad availability of the double-marking strategy however it was only used in 37 sentences, which constitute $17 \%$ of all the sentences in the data (as opposed to the phonetic strategy which was used in $68 \%$ of the sentences in the data). Consequently, although the double-marking strategy is the second most frequent strategy in the data, it was only used in a very small minority of the cases where it was in principle available, suggesting that it is a relatively marginal focusing strategy. The double-marking strategy is illustrated in examples (15-17):

(15) Normal sentence with content verb (no seal=on täiesti korralik linnaekskursioon.)

ee 'Hermitaažis käiakse...

uh Hermitage.Iness go.IMPERS

'(Well there's a very good city tour.) They go to the Hermitage...'

(16) Normal sentence with copula

(A: meil=on eri 'hinnad sõltuvalt 'vanusest [nii])

$\mathrm{B}:$ [e] 'üliõpilane olen.

uh student.Nom be.1sg

(A: 'We have different prices depending on the age.') B: 'I'm a student.'

(17) Subject-final sentence

( $a g a={ }^{\prime}$ praegu mitte $=$ mingeid grupireise e $i=$ ole $)$

ainult 'Lapimaad on $=$ veel sellel aastal

only Lapland.PART be.3 still this.ADESS year.ADESS

'(But at present there are no group tours,) there's only Lapland this year'

Compared to the phonetic and the double-marking strategy, the syntactic and the phonological strategy were available in much more limited cases: (i) in the sentences where the focus was on a constituent whose neutral position is sentence-initial (the subject in normal sentences and the setting adjunct or the oblique argument in subjectfinal sentences; see ex. 18 below), (ii) in the sentences where the focus was on the complement of a complex predicate, which precedes the 
non-finite element of the complex predicate in the unmarked order (see ex. 19-21 below), and (iii) in the sentences where the focus was on the non-final verbal complement if there were several (see ex. 23 below). In the latter two cases, focus can be marked using either the syntactic, the phonological or the double-marking strategy; in the first case, only the syntactic and the phonological strategy are available. The number of such cases and the focusing strategies used in these cases are presented in Table 2.

Table 2. The distribution of the syntactic, phonological and doublemarking strategy in the contexts where both the syntactic and the phonogical strategy were in principle available.

\begin{tabular}{l|c|c|c|c} 
& Syntactic & $\begin{array}{c}\text { Phono- } \\
\text { logical }\end{array}$ & Double & Total \\
\hline $\begin{array}{l}\text { Focus on a neutrally sentence- } \\
\text { initial constituent }\end{array}$ & 0 & 7 & NA & 7 \\
\hline $\begin{array}{l}\text { Focus on the complement of a } \\
\text { complex predicate }\end{array}$ & 12 & 12 & 10 & 34 \\
\hline $\begin{array}{l}\text { Focus on a non-final verbal } \\
\text { complement }\end{array}$ & 3 & 0 & 0 & 3 \\
\hline TOTAL & 15 & 19 & 10 & 44
\end{tabular}

As can be seen from the table, the data contained only 7 instances where the focus was on a constituent whose neutral location is sentenceinitial (which is not unexpected given that the neutrally sentence-initial constituent tends to coincide with the topic, cf. Lambrecht 1994: 131-137). In all these cases, it was focused phonologically, leaving the syntactic structure unmarked, cf. (18). This gives some support to the hypothesis that the phonological strategy may be the preferred strategy for marking non-final focus in spoken discourse, although the number of relevant instances in the data is extremely small.

(18) Phonologically expressed subject focus:

(A: ja: seal sees on $=$ sis 'viisa $=j a$

B: $<$ ee seal=on 'viisa $=e e$ : 'ööbimised $=e e$ kaks=ee. hh õhtusööki: $k a k s$ 'hommikusööki > .hh) 


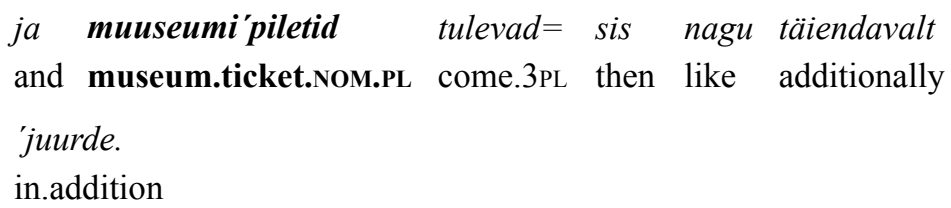

(A: 'And so it includes the visa and...' B: 'There's the visa, the accommodations, two suppers, two breakfasts.) And the museum tickets come on top of this.'

The total number of sentences with a complex predicate in the data was 36. Two of these were analysed as instantiating the phonetic strategy because the non-finite element of the predicate was topicalised. From the remaining 34 sentences, 12 displayed the syntactic strategy, 12 the phonological strategy, and 10 the double-marking strategy, e.g. (components of the complex predicate are not in italics):

(19) Syntactic strategy:

kui tahate vaadata nüd 'Soome reisikorraldajate

if want.2PL look.INF now Finnish tour.operator.GEN.PL

\section{kaudu}

through

'If you want to look now through the Finnish tour operators'

(20) Phonological strategy:

( noh $m a=e i=$ tea mida te silmas peate.

$k u i=t e=$ \{sellist $\} \quad$ rühmareisi silmas peate

if 2.PL such.PART group.tour.PART mind.INESS have.2PL

'I don't know what you have in mind. If you have in mind a group tour'

(21) Double-marking strategy:

([saate] 'sõita põtradega, .hh)

mootor'kelguga saate sõita

snowmobile.com can.2PL ride.INF

'(You can ride with reindeers, ) you can ride with a snowmobile.'

Consequently, in this category, all three strategies were equally frequent. However, the instances representing the syntactic strategy include a number of cases where the focus constitutes a separate prosodic phrase (six as compared to just one case in the phonological 
category and two cases in the double-marking category). The reason for the separate phrasing of the focus constituent does not seem to be focus marking but rather the fact that the speaker is still searching for the information to be given and therefore postpones uttering the focal constituent. For instance, in (22), the focal constituent is preceded by a relatively long pause and the thematic part of the sentence is slowed down, suggesting that the focal constituent is being postponed.

(22) Syntactic strategy; focus constitutes a separate prosodic phrase:

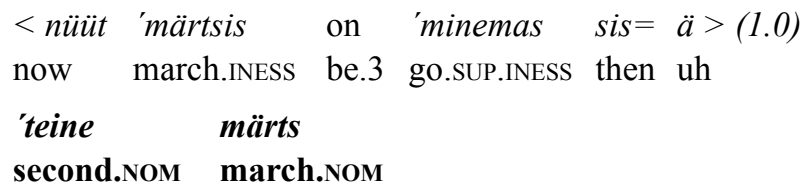

'In march there's one uh ... on 2 March'

Table 3 summarises all the instances in the data where the narrow focus constitutes a separate phrase. As can be seen, the separate phrasing of the focus is overall relatively rare, including in the case of early focus. The fact that it is most frequent in the syntactic focus-marking category thus supports the supposition that the use of the syntactic strategy may in some cases have been prompted by the need to postpone the focal constituent.

Table 3. The number of separately phrased focal constituents in each of the four focus-marking categories (second column), and the proportion of the separately phrased cases with respect to the total number of instances in each category (third column).

\begin{tabular}{l|c|c|c} 
& Total & Separately phrased (N) & Separately phrased (\%) \\
\hline Phonetic & 147 & 21 & $14 \%$ \\
\hline Syntactic & 15 & 6 & $40 \%$ \\
\hline Phonological & 18 & 2 & $11 \%$ \\
\hline Double & 37 & 3 & $8 \%$ \\
\hline TOTAL & 217 & 32 & $15 \%$
\end{tabular}

In conclusion, assuming that the syntactic strategy has partly been used for postponing reasons, the phonological strategy could be considered to be slightly more preferred in sentences containing a complex predicate. However, the double-marking strategy is almost equally frequent and the numbers are overall very small. 
The third case where either the syntactic or the phonological strategy was in principle available were the sentences where the focus was on a non-final verbal complement (in case there were several). There were only three cases where a non-final VP constituent was focused, and in all these the syntactic strategy was used (23). None of these cases involved separate phrasing of the focus. Consequently, in these very rare cases the syntactic strategy was preferred.

(23) Focused adjunct follows the object:

('üks võimalus on et $=e e$ )

et $=$ ostate kogu paketi 'siit.

that buy.2PL whole package.PART here

'(One possibility is that uh) that you buy the whole package here.'

\section{Discussion}

The strongly preferred focusing strategy in the data is the phonetic strategy, where the unmarked syntactic position of the focused constituent is sentence-final and coincides with the neutral location of the nuclear accent, the narrow focus being presumably expressed by phonetic emphasis. This situation is probably favoured by the fact that the unmarked syntactic structure can be considered to reflect the pragmatic and prosodic preferences: whereas the neutrally sentence-initial subject tends to be the topic, the neutrally sentence-final complements tend to be foci. Consequently, the probability of the phonetic focusmarking strategy is larger than that of the others.

On the other hand, it is possible that part of the sentences in the phonetic focus-marking category result in fact from a syntactic strategy, in the sense that the syntactic structure of the sentences may have been chosen so that the focal information would occur neutrally in the sentence-final position. This is suggested by the fact that the phonetic strategy is most frequent in copular sentences, which in turn are the most frequent sentence type in the data. Consequently, the large proportion of the phonetic strategy may also reflect an effort for keeping both the prosody and the constituent order unmarked. This is in line with the finding of Lindström (2005) that word order varies less in spoken language than in written language. However, the concomitant of this fact is not a larger variability in prosody, as could be hypothesised. On the contrary, in the large majority of the sentences the nuclear accent 
occurs sentence-finally, which can be considered to be its unmarked position. Overall, the focal constituent occurs in its unmarked syntactic position in $76 \%$ of the cases and the nuclear accent is in the unmarked position in $75 \%$ of the sentences in the data. This double unmarkedness seems to be achieved primarily by using a relatively restricted set of syntactic structures (in particular, copular sentences) that permit to keep both the syntax and the prosody unmarked.

Note however that not all the sentences where the focus constituent is in its unmarked syntactic position are syntactically entirely unmarked as they may contain marked topics (i.e. constituents whose unmarked position is not sentence-initial occurring in the initial topic position) and right-dislocated constituents. With regard to topic marking there does not seem to exist a prosodic alternative to syntactic topicalisation: topics have not been found to correlate with a specific pitch accent type, and in a perception test no difference was perceived between predicatefocus and sentence-focus sentences (i.e. sentences with and without a topic), unlike between these two types of broad-focus sentences and the sentences with initial or final narrow focus (Sahkai et al. 2014). Topics can therefore only be marked syntactically, both in written and in spoken language.

The possibility of the occurrence of the remaining focus-marking strategies is varying. The double-marking strategy is potentially available whenever the unmarked position of the focal constituent is not sentence-initial, which is the case in $97 \%$ of the instances. The fact that it is much less frequent than the phonetic strategy thus shows that it is a minor focusing strategy. Nevertheless, the existence of a focusing strategy that involves both syntactic and prosodic markedness seems unexpected, given the simultanous preference for both to be unmarked, and given the fact that the prosodic and the syntactic focus-marking strategy have been assumed to be complementary (Vallduví 1991). Tael (1988) associates the initial focus with contrastivity; É. Kiss (1998a,b) associates the availability of both a final and an initial focus position with a semantic and syntactic distinction between identificational (exhaustive) and information focus. The present data does not seem to support the hypothesis that the initial focus is contrastive: only three of the doubly marked focus constituents can be interpreted as being contrasted with another referent in the context. As to exhaustivity, the initial focus clearly occurs in utterances where it is not intended as exhaustive, see for instance the examples (15) and (21) above. It could further be hypothesised that the instances of this strategy involve the right dislocation of the thematic part of the sentence, i.e. that the focal 
constituent was initially intended as an isolated phrase, the remainder of the sentence having been added as an afterthought or clarification. This hypothesis would be confirmed if the focused constituent tended to be followed by a prosodic boundary. However, this is the case only in three instances. In sum, more study is needed in order to explain the role of the doubly marked focus fronting strategy in Estonian.

As to the syntactic and the phonological focus-marking strategy, the fact that most narrow foci in the data occur neutrally in sentence-final position means that the number of sentences where it was in principle possible to use these strategies and to choose between them was small. On the basis of these limited instances it could be concluded that there is a slight preference for the phonological strategy, considering that it is the only strategy used to focus constituents whose neutral location is sentence-initial, and that some of the instances of the syntactic strategy used in the sentences with a complex predicate are due to postponing rather than focus marking.

\section{Conclusion}

The strongest preference in the expression of narrow focus in spoken Estonian is to keep both the constituent order and the nuclear accent placement unmarked, possibly by employing a large proportion of copular sentences.

When either the unmarked constituent order or the unmarked nuclear accent placement needs to be modified, i.e. in the rare cases where the unmarked position of the focused constituent is not sentence-final, there is a slight preference for modifying the prosody rather than the syntax: only the phonological strategy is used to focus constituents whose neutral location is sentence-initial, and the syntactic strategy seems to be used partly for postponing rather than focus marking.

At the same time, there exists the minor strategy of focus fronting, which involves both marked constituent order and marked nuclear accent placement; the exact role of this strategy requires further study as it does not seem to be due to neither contrastivity or exhaustivity nor to dislocation.

The results of the study further show that separate phrasing is generally not used to mark narrow focus. It is relatively most frequent in sentences exhibiting the syntactic focus-marking strategy and seems partly to be related to postponing. 


\title{
Acknowledgements
}

This research has been supported by the Centre of Excellence in Estonian Studies (CEES, European Regional Development Fund) and is related to research project IUT35-1 (Estonian Research Council).

\author{
Address \\ Heete Sahkai \\ Institute of the Estonian Language \\ Roosikrantsi 6, 10119 Tallinn \\ E-mail: heete.sahkai@eki.ee
}

\begin{abstract}
Abbreviations
ADESS - adessive, ALL - allative, CMPR - comparative, COM - comitative, COMP - complementiser, COND - conditional, ELAT - elative, EMPH - emphatic particle, GEN - genitive, ILL - illative, IMPERS - impersonal, INESS - inessive, INF - infinitive, PART - partitive, PRTCL - particle, PRTCPL - participle, QUOT - quotative, REL - relative pronoun, SUP supine, TERM - terminative, TRANSL - translative
\end{abstract}

\section{References}

Asu, Eva Liina, Pärtel Lippus, Nele Salveste, and Heete Sahkai (2016) "F0 declination in spontaneous Estonian: implications for pitch-related preplanning in speech production". Proceedings of Speech Prosody 2016, Boston University.

É. Kiss, Katalin (1987) Configurationality in Hungarian. Dordrecht: Reidel.

É. Kiss, Katalin (1998a) "Identificational focus versus information focus". Language $74,2,245-273$.

É. Kiss, Katalin (1998b) "Discourse-configurationality in the languages of Europe". In A. Siewierska, ed. Constituent order in the languages of Europe, 681-729. Berlin: Mouton de Gruyter.

Erelt, Mati, Reet Kasik, Helle Metslang, Henno Rajandi, Kristiina Ross, Henn Saari, Kaja Tael, and Silvi Vare (1993) Eesti keele grammatika II. Süntaks. Lisa: kiri. Tallinn: Eesti Teaduste Akadeemia Keele ja Kirjanduse Instituut.

Jun, Sun-Ah (2005) "Prosodic typology". In S.-A. Jun, ed. Prosodic typology: the phonology of intonation and phrasing, 430-458. Oxford: Oxford University Press.

Ladd, D. Robert (2008) Intonational phonology. Cambridge: Cambridge University Press. 
Ladd, D. Robert and Rachel Morton (1997) “The perception of intonational emphasis: continuous or categorical?" Journal of Phonetics 25, 313-342.

Lambrecht, Knud (1994) Information structure and sentence form. Cambridge: Cambridge University Press.

Lindström, Liina (2005) Finiitverbi asend lauses. Sõnajärg ja seda mõjutavad tegurid suulises eesti keeles. (Dissertationes filologiae estonicae universitatis tartuensis, 16.) Tartu: Tartu Ülikooli Kirjastus.

Lindström, Liina (2017) “Lause infostruktuur ja sõnajärg”. In M. Erelt and H. Metslang, eds. Eesti keele süntaks. (Eesti keele varamu, 3.), 547-565. Tartu: Tartu Ülikooli Kirjastus.

Mihkla, Meelis, Heete Sahkai, and Mari-Liis Kalvik (2015) “Acoustic correlates of emphasis in Estonian". Proceedings of the 18th International Congress of Phonetic Sciences, Glasgow, August 6-10, 2015. 1-5.

Nurme, Maili (2012) “Impersonaali objekt". Keel ja Kirjandus, 5, 335-344.

Sahkai, Heete (1999) "Eesti verbifraasi sõnajärg”. Keel ja Kirjandus, 1, 24-32.

Sahkai, Heete, Mari-Liis Kalvik, and Meelis Mihkla (2013) "Prosodic effects of information structure in Estonian". In E. L. Asu and P. Lippus, eds. Nordic prosody. Proceedings of the XIth Conference, Tartu 2012, 323-332. Frankfurt am Main: Peter Lang.

Sahkai, Heete, Mari-Liis Kalvik, and Meelis Mihkla (2014) "Perception of focus size and focus type in Estonian”. In K. Jähi and L. Taimi, eds. XXVIII Fonetiikan päivät. Turku 25.-26. lokakuuta 2013. Konferenssijulkaisu. Turku: Turun yliopisto, 72-79. Available online at $<$ http://urn.fi/URN:ISBN:978-951-29-5980-8>. Accessed on 21.04.2017.

Sahkai, Heete, Meelis Mihkla, and Mari-Liis Kalvik (2015) "Emfaas ja fookus eesti keeles". Journal of Estonian and Finno-Ugric Linguistics 6, 3, 97-122.

Salveste, Nele (2013) "Focus perception in Estonian: is it governed by syntax or prosody?" In E. L. Asu and P. Lippus, eds. Nordic prosody. Proceedings of the XIth Conference, Tartu 2012, 333-342. Frankfurt am Main: Peter Lang Edition.

Salveste, Nele (2015) On the pragmatic and semantic functions of Estonian sentence prosody. Ph.D. dissertation, Ludwig-Maximilian-Universität München. Available online at $<$ https://edoc.ub.uni-muenchen.de/18943/>. Accessed on 21.04.2017.

Tael, Kaja (1988) Sõnajärjemallid eesti keeles (võrrelduna soome keelega). [Word order patterns in Estonian (in comparison with Finnish).] (Preprint, KKI-53.) Tallinn: Eesti NSV Teaduste Akadeemia Keele ja Kirjanduse Instituut.

Vallduví, Enric (1991) "The role of plasticity in the association of focus and prominence". In Y. No, and M. Libucha, eds. Proceedings of the Seventh Eastern States Conference on Linguistics, 295-306. Ohio: The Ohio State University.

Van Valin, Robert D. Jr. (1999) “A typology of the interaction of focus structure and syntax". In E. Raxilina, J. Testelec, eds. Typology and the theory of language: from description to explanation, 511-524. Moscow: Languages of Russian Culture.

Vilkuna, Maria (1989) Free word order in Finnish: its syntax and discourse functions. Helsinki: Suomalaisen Kirjallisuuden Seura. 
Kokkuvõte. Heete Sahkai: Kitsa fookuse väljendamine eestikeelses suulises dialoogis. Eesti keel võimaldab väljendada kitsast fookust muuhulgas nii moodustajajärje kui primaarse lauserõhu asukoha abil. Artiklis vaadeldakse kitsa fookuse väljendamist reisibüroo dialoogides peamise eesmärgiga kontrollida hüpoteesi, et suulises kõnes eelistatakse süntaktilisele fookuse väljendamisele prosoodilist. Tulemused näitavad tugevat eelistust lausungite suhtes, kus on samaaegselt nii markeerimata moodustajajärg kui ka markeerimata prosoodia. Juhtumeid, kus tuleb valida kas markeeritud moodustajajärg või markeeritud prosoodia, on suhteliselt vähe ning nende põhjal võib järeldada, et prosoodiline markeerimine on tõepoolest mõnevõrra eelistatud. Edasist uurimist nõuab andmestikus vähesel määral esindatud lausealguline fookus, mille puhul on markeeritud nii moodustajajärg kui primaarse lauserõhu asukoht.

Võtmesõnad: fookus, moodustajajärg, lauserõhk, eesti keel 